r ScIDice

\section{Assessment of Periodontal Splinting Procedures Done Using Fiber and Composite Versus Wire and Composite}

Research Article

Aniruddh Menon ${ }^{1}$, Nashra Kareem²* Jayanth Kumar Vadivel ${ }^{3}$

${ }^{1}$ Saveetha Dental College and Hospital, Saveetha Institute of Medical and Technical Sciences, Saveetha University, Chennai 600077, Tamil Nadu, India. ${ }^{2}$ Senior Lecturer, Department of Periodontics, Saveetha Dental College and Hospital, Saveetha Institute of Medical and Technical Sciences, Saveetha University, Chennai 600077, Tamil Nadu, India.

${ }^{3}$ Reader, Department of Oral Medicine and Radiology, Saveetha Dental College and Hospital, Saveetha Institute of Medical and Technical Sciences, Saveetha University, Chennai 600077, Tamil Nadu, India.

\title{
Abstract
}

The most common indication for periodontal splinting is to improve the prognosis of mobile teeth and patient comfort and provide better control of the occlusion if the anterior teeth are mobile, which is much widely accepted by the patient rather than extensive and invasive long term periodontal surgery and regenerative procedures. The aim of the present study is to assess the Prevalence of the Fiber with composite vs wire with composite for splinting at Saveetha Dental College. Retrospective data of 281 patients was obtained and segregated. The inclusion criteria included 6-70 years age group, underwent frenectomy/frenotomy and visited between June 2019 to April 2020. Once the data was obtained it was statistically analyzed using SPSS by IBM version 20. Within the limits of the present study it is observed that the most commonly used material for splinting is wire and composite than Fiber and composite. Based on correlation and association tests a positive correlation was noticed between the type of splinting and the duration of splinting with a high statistical significance $(\mathrm{p}=0.001)$. Further awareness programmes that should be conducted to bring out better clinical outcomes and help the society holistically.

Keywords: Splinting; Fibre; Composite; Periodontitis.

\section{Introduction}

Periodontitis is an inflammatory disease induced by bacterial biofilms that accumulate in the gingival margin and characterized by gingival inflammation, loss of connective tissue attachment and alveolar bone [1-3]. Various systemic complications can worsen the periodontal status as well [4-5]. Removal of plaque, calculus, elimination of deep periodontal pockets and occlusal adjustment are treatment options and result in healthy periodontium but reduced height of the supporting tissues [6]. If left untreated, the continuous loss of the supporting tissues during periodontal disease progression may result in increased tooth mobility, ultimately yielding to tooth drifting and exfoliation[7-10]. Tooth mobility can also be a consequence of occlusal trauma in addition to the periodontal inflammation and attachment loss which is caused due a large group of sequential events mediated by many genetic, cellular and other chemical modulators [11].
From the clinical point of view, it is important to clarify the reason for increased tooth mobility as a result of widened periodontal ligament, reduced height of the supporting tissues or their combination [12]. Tooth mobility is a result of intra-alveolar displacement of the root and usually assessed by exposing the crown of the tooth to a certain force and determining the distance that the crown can be displaced in buccal and/or lingual direction [13]. Assessment of tooth mobility could be performed manually/digitally or with the help of instruments such as periodontometer, the laser vibrometry, Periotest and photogrammetric measurement method [14-17]. A commonly used device, Periotest, measures the reaction of the periodontium to a defined percussion force that is applied to the tooth and delivered by a tapping instrument. The Periotest values range from -8 to + 50 where the firm teeth demonstrate values ranging from -8 to +9 and mobile ones at a range of 30 to 50 [15]. The mobility of a tooth in the horizontal direction is closely dependent on the height of the surrounding supporting bone, the width and quality

\section{*Corresponding Author}

Nashra Kareem,

Senior Lecturer, Department of Periodontics, Saveetha Dental College and Hospital, Saveetha Institute of Medical and Technical Sciences, Saveetha University, Chennai 600077, Tamil Nadu, India.

E-mail: nashrak.sdc@saveetha.com

Received: July 30, 2021

Accepted: August 11, 2021

Published: August 18, 2021

Citation: Aniruddh Menon, Nashra Kareem, Jayanth Kumar Vadivel. Assessment of Periodontal Splinting Procedures Done Using Fiber and Composite Versus Wire and Composite. Int J Dentistry Oral Sci. 2021;8(8):4000-4004. doi: http://dx.doi.org/10.19070/2377-8075-21000817

Copyright: Nashra Kareem ${ }^{\circ}$ 2021. This is an open-access article distributed under the terms of the Creative Commons Attribution License, which permits unrestricted use, distribution and reproduction in any medium, provided the original author and source are credited. 
of the periodontal ligament, and the shape and number of roots present[18-20]. Mobility could cause occlusal instability, discomfort or pain during function [21]. Occlusal instability could have negative consequences on tooth tissue relationship, including the relationship of the teeth to the opposing dentition that could lead to excessive occlusal forces [6]. The question is whether a healthy periodontium with reduced height has a capacity similar to that of the normal periodontium to adapt to traumatizing occlusal forces.

The most common indication for periodontal splinting is to improve the prognosis of mobile teeth and patient comfort and provide better control of the occlusion if the anterior teeth are mobile [22], which is much widely accepted by the patient rather than extensive and invasive long term periodontal surgery and regenerative procedures [23-29]. Periodontal splints that redistribute functional and parafunctional forces achieve stability after periodontal treatment [30]. The aim of the present study is to assess the Prevalence of the Fiber with composite vs wire with composite for splinting.

\section{Materials and Methods}

The present study involved a total of 281 patients that underwent splinting procedures. These included all treatment modalities of splinting. The study was performed in a university setting at Saveetha Dental College and Hospitals. Thus the data obtained from the patients is of the same geographic location and ethnicity. The ethical approval for collection of retrospective data from the dental patient management archives was obtained from the Institutional Ethics Board.

The period of the study was between June 2019 to April 2020. Once the data was collected the same was verified by using photographs by two external reviewers who were blinded on the hypothesis from the present study. This was done to eliminate the chances of sampling bias. Before the commencement of the study a clear well defined inclusion criteria was defined. The inclusion criteria included that:

- Patients should have visited Saveetha Dental College during the study period.

- Patient has been treated by a resident of Saveetha Dental College, either an undergraduate or postgraduate student.

- Should have undergone splinting procedures.

\section{- Should have been within the age group of 6 - 70 years.}

Out of the study population that was chosen for the study there was no segregation process, as this would result in sampling bias. The data segregation was done according to various parameter such as speciality of clinic in which patient was treated, age of the patient, gender of the patient etc.

The data that was then tabulated was reviewed by an external reviewer and screened for internal validity of the study. The data was then exported to SPSS Software by IBM Version 20 for Statistical Analysis. Descriptive statistics was performed followed by Correlation tests to see any kind of correlation or Association between the different variables taken in the present study. Previously our team has a rich experience in working on various research projects across multiple disciplines [31-45]. Now the growing trend in this area motivated us to pursue this project.

\section{Results \& Discussion}

The present study consisted of 281 patients who had undergone splinting with wire and composite, and Fiber and composite at Saveetha Dental College. Out of the entire study population, $59.1 \%$ are males and $40.9 \%$ are females. The patients were between the age group of $16-70$ years with a mean age of 37.2 plus or minus 11.8 years.

Out of the total the splinting procedures wire and composite was used $85.1 \%$ whereas Fiber and Composite $14.9 \%$. Based on duration provisional splinting was the most widely performed type $(59.1 \%)$ followed by Temporary $(34.5 \%)$ and finally permanent (6.4\%). Lower arch was the more commonly seen arch where splinting was performed, $63 \%$ and in the upper arch $37 \%$ was performed.

Based on correlation and association tests a positive correlation was noticed between the type of splinting and the duration of splinting with a high statistical significance $(p=0.001)$. There was also a strong correlation seen between the duration of splinting and the arch in which it was performed. Permanent splinting was performed more commonly in the upper arch whereas provisional and temporary splinting were performed in the lower arch. It had a $p=0.000$ which showed high statistical significance. There

Graph 1: This bar graph shows the association between the duration of splinting and the material used where blue colour denotes splinting done with wire and composite and green colour denotes splinting with fibre and composite. The $\mathrm{X}$ axis denotes the type of splinting and $\mathrm{Y}$ axis denotes the number of patients having undergone the procedures. This graph denotes that the most widely preferred duration of splinting is provisional splinting and in all three durations of splinting the most commonly used material is wire and composite. Chi-square test was done and the association was found to be statistically significant. Pearson's Chi-square value $=14.702$, $\mathrm{df}=2$, $\mathrm{p}$ value $0.001(<0.05)$ hence statistically significant. $\mathrm{p}<0.05$-Infers Statistically Significant association between material and duration for splinting.

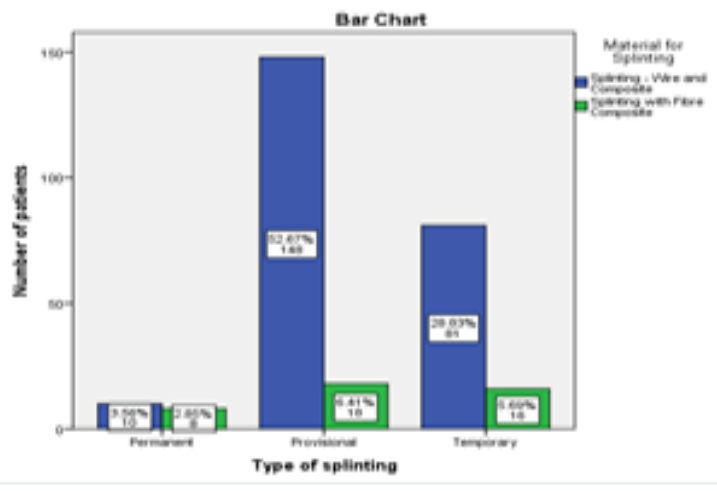


Graph 2: Bar chart shows association between the duration of splinting and the different arches where blue colour denotes the upper arch and green colour denotes the lower arch. In the graph $\mathrm{X}$ axis denotes the type of splinting based on duration and $\mathrm{Y}$ axis denotes the number of patients having undergone the procedures. Permanent splinting is performed more in the upper arch than the lower arch whereas provisional and temporary splinting is performed more frequently in the lower arch than in the upper arch. Chi-square test was done and the association was found to be statistically significant. Pearson's Chi-square value $=40.696, \mathrm{df}=6$, $\mathrm{p}$ value $0.00(<0.05)$ hence statistically significant. $\mathrm{p}<0.05$-Infers Statistically Significant association between duration of splinting and arch for splinting.

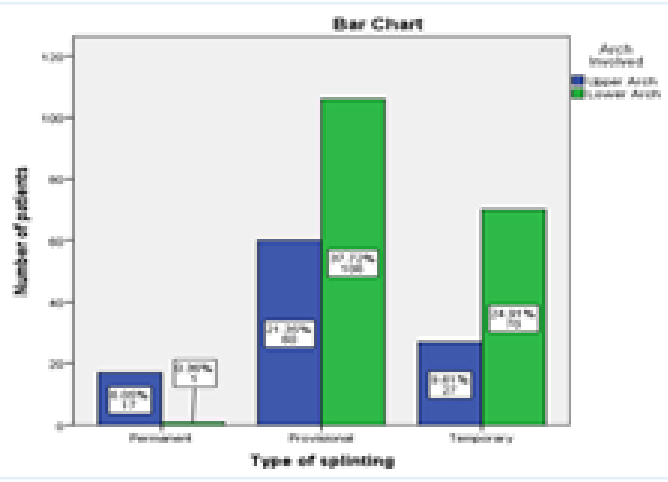

Graph 3: Bar chart shows association between the duration of splinting and the age of the patient where blue colour denotes permanent splinting, green colour denotes provisional splinting and yellow colour denotes temporary splinting. $\mathrm{X}$ axis denotes the age group and $\mathrm{Y}$ axis denotes the number of patients having undergone the procedures. Provisional splinting is more prevalent within the 31-40 years age group, permanent splinting is more prevalent in the 41-50 years age groups and temporary splinting is more common in the 31-40 years age group. Chi-square test was done and the association was found to be statistically insignificant. Pearson's Chi-square value $=15.175$, df $=10$, $p$ value $0.126(>0.05)$ hence statistically not significant. $p>0.05$-Infers no Statistically Significant association between duration of splinting and age of the patient.

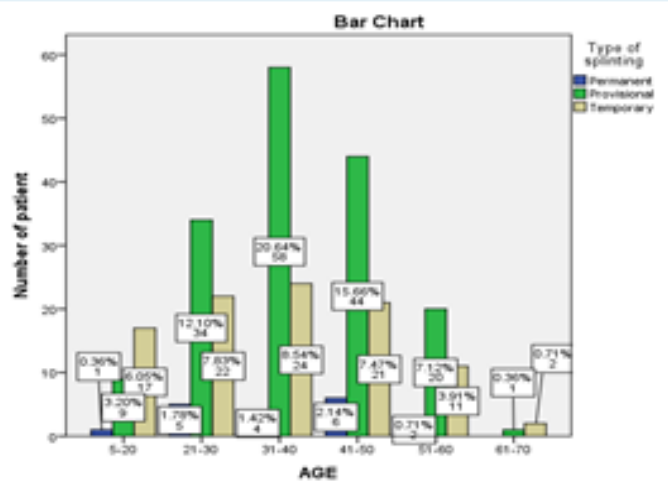

was no statistical significance between age of the patient and the duration of splinting $(\mathrm{p}>0.05)$

Numerous types of splints have been described in the literature, such as composite resin based ones used in conjunction with adhesive systems, orthodontic wire, wire-composite [46] or fiber reinforced composite resin [47], nylon fishing line-composite and polyethylene [48]. To the authors ` best knowledge, the impact of tooth mobility on the survival of splint materials considering also the periodontal parameters have not been assessed to date. Within the limits of the present study it is observed that males undergo splinting more than females.

In a study conducted by Bhawna $G$ et al., [49] where the prevalence of smoking was assessed on a national survey it was observed that males had more usage than females, it is a well known fact that has been documented through the ages that there is a clear relationship between smoking and its effect of periodontal health [50]. Thus this could be the reason why males undergo splinting more than females. It is observed that the most commonly used material is wire and composite as compared to fibre and composite. There are various reasons for the same. This can be attributed to the fact that there were more chances of debonding or detachment in the case of Fiber retainers as reported by
Sobouti et al., [51] in a randomised control trial. In another clinical study conducted by Aliye Akcali et al.,[52] where the clinical parameters were considered there was no difference in the clinical parameters that were measured with both these materials. There is a positive correlation between the arch and the type of material that is used, this can be attributed to the fact that there Is an increased aesthetic demand when the upper arch is considered. There is an added advantage of better esthetics when Fiber and Composite is considered, thus there should be further studies and further awareness programmes that should be conducted to bring out better clinical outcomes and help the society holistically. Our institution is passionate about high quality evidence based research and has excelled in various fields [53-63]. We hope this study adds to this rich legacy.

The limitations of the present study included that it was single centered and thus all the patients were geographically isolated. Clinical parameters were not considered in accounting during the present study.

\section{Conclusion}

Within the limits of the present study it is observed that the most commonly used material for splinting is wire and composite than 
Fiber and composite. Further awareness programmes that should be conducted to bring out better clinical outcomes and help the society holistically.

\section{References}

[1]. Suwal P. 'General Systemic Evaluation of Prosthodontic Patients: A Literature Review', 2013;13(2):90-94.

[2]. Pihlstrom BL, Michalowicz BS, Johnson NW. Periodontal diseases. Lancet. 2005 Nov 19;366(9499):1809-20.

[3]. Mootha A, Malaiappan S, Jayakumar ND, Varghese SS, Toby Thomas J. The Effect of Periodontitis on Expression of Interleukin-21: A Systematic Review. Int J Inflam. 2016;2016:3507503.Pubmed PMID: 26998377.

[4]. Varghese SS, Thomas H, Jayakumar ND, Sankari M, Lakshmanan R. Estimation of salivary tumor necrosis factor-alpha in chronic and aggressive periodontitis patients. Contemp Clin Dent. 2015 Sep;6(Suppl 1):S152-6. Pubmed PMID: 26604566

[5]. Ramesh A, Varghese SS, Jayakumar ND, Malaiappan S. Chronic obstructive pulmonary disease and periodontitis-unwinding their linking mechanisms. J. Oral Biosci. 2016 Feb 1;58(1):23-6.

[6]. Priyanka S, Kaarthikeyan G, Nadathur JD, Mohanraj A, Kavarthapu A. Detection of cytomegalovirus, Epstein-Barr virus, and Torque Teno virus in subgingival and atheromatous plaques of cardiac patients with chronic periodontitis. J Indian Soc Periodontol. 2017 Nov-Dec;21(6):456-460.Pubmed PMID: 29551863.

[7]. Foz AM, Artese HP, Horliana AC, Pannuti CM, Romito GA. Occlusal adjustment associated with periodontal therapy--a systematic review. J Dent. 2012 Dec;40(12):1025-35.Pubmed PMID: 22982113.

[8]. Herrera D, Roldán S, González I, Sanz M. The periodontal abscess (I). Clinical and microbiological findings. J Clin Periodontol. 2000 Jun;27(6):38794.

[9]. Khalid W, Vargheese SS, Lakshmanan R, Sankari M, Jayakumar ND. Role of endothelin-1 in periodontal diseases: A structured review. Indian J Dent Res. 2016 May-Jun;27(3):323-33.Pubmed PMID: 27411664.

[10]. Khalid W, Varghese SS, Sankari M, Jayakumar ND. Comparison of Serum Levels of Endothelin-1 in Chronic Periodontitis Patients Before and After Treatment. J Clin Diagn Res. 2017 Apr;11(4):ZC78-ZC81.Pubmed PMID: 28571268.

[11]. Avinash K, Malaippan S, Dooraiswamy JN. Methods of Isolation and Characterization of Stem Cells from Different Regions of Oral Cavity Using Markers: A Systematic Review. Int J Stem Cells. 2017 May 30;10(1):12-20. Pubmed PMID: 28531913

[12]. Ramamurthy JA, Mg V. Comparison of effect of Hiora mouthwash versus Chlorhexidine mouthwash in gingivitis patients: A clinical trial. Asian J Pharm Clin Res. 2018 Jul 7;11(7):84-8.

[13]. Nyman SR, Lang NP. Tooth mobility and the biological rationale for splinting teeth. Periodontol 2000. 1994 Feb;4(1):15-22.

[14]. Nyman S, Lindhe J. Persistent tooth hypermobility following completion of periodontal treatment. J Clin Periodontol. 1976 May;3(2):81-93.Pubmed PMID: 1064597.

[15]. Mühlemann HR. Tooth Mobility: The Measuring Method. Initial and Secondary Tooth Mobility. J Periodontol. 1954 Jan;25(1):22-9.

[16]. Schulte W, d'Hoedt B, Lukas D, Maunz M, Steppeler M. Periotest for measuring periodontal characteristics--correlation with periodontal bone loss. J Periodontal Res. 1992 May;27(3):184-90.Pubmed PMID: 1608031.

[17]. Castellini P, Scalise L, Tomasini EP. Teeth mobility measurement: a laser vibrometry approach. J Clin Laser Med Surg. 1998 Oct;16(5):269-72.Pubmed PMID: 9893508.

[18]. Goellner M, Berthold C, Holst S, Wichmann M, Schmitt J. Correlations between photogrammetric measurements of tooth mobility and the Periotest method. Acta Odontol Scand. 2012 Jan;70(1):27-35.Pubmed PMID: 21504267.

[19]. Mühlemann HR. 10 years of tooth-mobility measurements. J. Periodontol. 1960 Apr;31(2):110-22.

[20]. Persson R. Assessment of tooth mobility using small loads. II. Effect of oral hygiene procedures. J Clin Periodontol. 1980 Dec;7(6):506-15.Pubmed PMID: 7012187.

[21]. Persson R. Assessment of tooth mobility using small loads. III. Effect of periodontal treatment including a gingivectomy procedure. J Clin Periodontol. 1981 Feb;8(1):4-11.Pubmed PMID: 6941976.

[22]. Serio FG. Clinical rationale for tooth stabilization and splinting. Dent Clin North Am. 1999 Jan 1;43(1):1-6.

[23]. Forabosco A, Grandi T, Cotti B. The importance of splinting of teeth in the therapy of periodontitis. Minerva Stomatol. 2006 Mar;55(3):87-97.Pubmed PMID: 16575381

[24]. Thamaraiselvan M, Elavarasu S, Thangakumaran S, Gadagi JS, Arthie T.
Comparative clinical evaluation of coronally advanced flap with or without platelet rich fibrin membrane in the treatment of isolated gingival recession. J Indian Soc Periodontol. 2015 Jan;19(1):66.

[25]. Ravi S, Malaiappan S, Varghese S, Jayakumar ND, Prakasam G. Additive Effect of Plasma Rich in Growth Factors With Guided Tissue Regeneration in Treatment of Intrabony Defects in Patients With Chronic Periodontitis: A Split-Mouth Randomized Controlled Clinical Trial. J Periodontol. 2017 Sep;88(9):839-845.Pubmed PMID: 28474968.

[26]. Panda S, Jayakumar ND, Sankari M, Varghese SS, Kumar DS. Platelet rich fibrin and xenograft in treatment of intrabony defect. Contemp Clin Dent. 2014 Oct; $5(4): 550$.

[27]. Ramesh A, Ravi S, Kaarthikeyan G. Comprehensive rehabilitation using dental implants in generalized aggressive periodontitis. J Indian Soc Periodontol. 2017 Mar;21(2):160.

[28]. Kavarthapu A, Thamaraiselvan M. Assessing the variation in course and position of inferior alveolar nerve among south Indian population: A cone beam computed tomographic study. Indian J Dent Res. 2018 JulAug;29(4):405-409.Pubmed PMID: 30127186.

[29]. Ramesh A, Vellayappan R, Ravi S, Gurumoorthy K. Esthetic lip repositioning: A cosmetic approach for correction of gummy smile - A case series. J Indian Soc Periodontol. 2019 May-Jun;23(3):290-294.Pubmed PMID: 31143013.

[30]. Ramesh A, Varghese SS, Doraiswamy JN, Malaiappan S. Herbs as an antioxidant arsenal for periodontal diseases. J Intercult Ethnopharmacol. 2016 Jan 27;5(1):92-6.Pubmed PMID: 27069730.

[31]. Soares PB, Fernandes Neto AJ, Magalhães D, Versluis A, Soares CJ. Effect of bone loss simulation and periodontal splinting on bone strain: Periodontal splints and bone strain. Arch Oral Biol. 2011 Nov;56(11):1373-81.Pubmed PMID: 21550587.

[32]. Jain AR. Prevalence of partial edentulousness and treatment needs in rural population of South India. World J. Dent. 2017 Jun;8(3):213-7.

[33]. Varghese SS, Ramesh A, Veeraiyan DN. Blended Module-Based Teaching in Biostatistics and Research Methodology: A Retrospective Study with Postgraduate Dental Students. J Dent Educ. 2019 Apr;83(4):445-450.Pubmed PMID: 30745352.

[34]. Ashok V, Ganapathy D. A geometrical method to classify face forms. J Oral Biol Craniofac Res. 2019 Jul 1;9(3):232-5.

[35]. Padavala S, Sukumaran G. Molar incisor hypomineralization and its prevalence. Contemp. Clin. Dent. 2018 Sep;9(Suppl 2):S246-50.

[36]. Ke Y, Al Aboody MS, Alturaiki W, Alsagaby SA, Alfaiz FA, Veeraraghavan VP, et al. Photosynthesized gold nanoparticles from Catharanthus roseus induces caspase-mediated apoptosis in cervical cancer cells (HeLa). Artif Cells Nanomed Biotechnol. 2019 Dec;47(1):1938-1946.Pubmed PMID: 31099261.

[37]. Ezhilarasan D. Oxidative stress is bane in chronic liver diseases: Clinical and experimental perspective. Arab J Gastroenterol. 2018 Jun;19(2):56-64.Pubmed PMID: 29853428.

[38]. Krishnan RP, Ramani P, Sherlin HJ, Sukumaran G, Ramasubramanian A, Jayaraj G, et al. Surgical Specimen Handover from Operation Theater to Laboratory: A Survey. Ann Maxillofac Surg. 2018 Jul-Dec;8(2):234-238. Pubmed PMID: 30693238.

[39]. Ezhilarasan D, Sokal E, Najimi M. Hepatic fibrosis: It is time to go with hepatic stellate cell-specific therapeutic targets. Hepatobiliary Pancreat Dis Int. 2018 Jun;17(3):192-197.Pubmed PMID: 29709350.

[40]. Pandian KS, Krishnan S, Kumar SA. Angular photogrammetric analysis of the soft-tissue facial profile of Indian adults. Indian J. Dent. Res. $2018 \mathrm{Mar}$ 1;29(2):137-43

[41]. Ramamurthy JA, Mg V. Comparison of effect of Hiora mouthwash versus Chlorhexidine mouthwash in gingivitis patients: A clinical trial. Asian J Pharm Clin Res. 2018 Jul 7;11(7):84-8.

[42]. Gupta P, Ariga P, Deogade SC. Effect of Monopoly-coating Agent on the Surface Roughness of a Tissue Conditioner Subjected to Cleansing and Disinfection: A Contact Profilometric In vitro Study. Contemp Clin Dent. 2018 Jun;9(Suppl 1):S122-S126.Pubmed PMID: 29962776.

[43]. Vikram NR, Prabhakar R, Kumar SA, Karthikeyan MK, Saravanan R. Ball Headed Mini Implant. J Clin Diagn Res. 2017 Jan;11(1):ZL02-3.

[44]. Paramasivam A, Vijayashree Priyadharsini J, Raghunandhakumar S. N6adenosine methylation $(\mathrm{m} 6 \mathrm{~A})$ : a promising new molecular target in hypertension and cardiovascular diseases. Hypertens Res. 2020 Feb;43(2):153154.Pubmed PMID: 31578458.

[45]. Palati S, Ramani P, Shrelin HJ, Sukumaran G, Ramasubramanian A, Don $\mathrm{KR}$, et al. Knowledge, Attitude and practice survey on the perspective of oral lesions and dental health in geriatric patients residing in old age homes. Indian J Dent Res. 2020 Jan-Feb;31(1):22-25.Pubmed PMID: 32246676.

[46]. Samuel SR, Acharya S, Rao JC. School Interventions-based Prevention of Early-Childhood Caries among 3-5-year-old children from very low socioeconomic status: Two-year randomized trial. J Public Health Dent. 2020 
Jan;80(1):51-60.Pubmed PMID: 31710096.

[47]. Ebeleseder KA, Glockner K, Pertl C, Städtler P. Splints made of wire and composite: an investigation of lateral tooth mobility in vivo. Endod Dent Traumatol. 1995 Dec;11(6):288-93.Pubmed PMID: 8617165.

[48]. Kumbuloglu O, Saracoglu A, Ozcan M. Pilot study of unidirectional E-glass fibre-reinforced composite resin splints: up to 4.5 -year clinical follow-up. J Dent. 2011 Dec;39(12):871-7.Pubmed PMID: 22001066.

[49]. Sekhar LC, Koganti VP, Shankar BR, Gopinath A. A comparative study of temporary splints: bonded polyethylene fiber reinforcement ribbon and stainless steel wire + composite resin splint in the treatment of chronic periodontitis. J Contemp Dent Pract. 2011 Sep 1;12(5):343-9.Pubmed PMID: 22269194.

[50]. Bhawna G. Burden of smoked and smokeless tobacco consumption in India - results from the Global adult Tobacco Survey India (GATS-India)2009-2010. Asian Pac J Cancer Prev. 2013;14(5):3323-9.Pubmed PMID: 23803124.

[51]. Kinane DF, Chestnutt IG. Smoking and periodontal disease. Crit Rev Oral Biol Med. 2000 Jul;11(3):356-65.

[52]. Sobouti F, Rakhshan V, Saravi MG, Zamanian A, Shariati M. Two-year survival analysis of twisted wire fixed retainer versus spiral wire and fiberreinforced composite retainers: a preliminary explorative single-blind randomized clinical trial. Korean J Orthod. 2016 Mar;46(2):104-10.Pubmed PMID: 27019825.

[53]. Akcalı A, Gümüş P, Özcan M. Clinical comparison of fiber-reinforced composite and stainless steel wire for splinting periodontally treated mobile teeth. Braz. Dent. Sci. 2014 Aug 25;17(3):39-49.

[54]. Vijayashree Priyadharsini J. In silico validation of the non-antibiotic drugs acetaminophen and ibuprofen as antibacterial agents against red complex pathogens. J Periodontol. 2019 Dec;90(12):1441-1448.Pubmed PMID: 31257588 .

[55]. Pc J, Marimuthu T, Devadoss P, Kumar SM. Prevalence and measurement of anterior loop of the mandibular canal using CBCT: A cross sectional study. Clin Implant Dent Relat Res. 2018 Apr 6;20(4):531-4.

[56]. Ramesh A, Varghese S, Jayakumar ND, Malaiappan S. Comparative estima- tion of sulfiredoxin levels between chronic periodontitis and healthy patients - A case-control study. J Periodontol. 2018 Oct;89(10):1241-1248.Pubmed PMID: 30044495.

[57]. Ramadurai N, Gurunathan D, Samuel AV, Subramanian E, Rodrigues SJ. Effectiveness of $2 \%$ Articaine as an anesthetic agent in children: randomized controlled trial. Clin Oral Investig. 2019 Sep;23(9):3543-50.

[58]. Sridharan G, Ramani P, Patankar S, Vijayaraghavan R. Evaluation of salivary metabolomics in oral leukoplakia and oral squamous cell carcinoma. J Oral Pathol Med. 2019 Apr;48(4):299-306.

[59]. Ezhilarasan D, Apoorva VS, Ashok Vardhan N. Syzygium cumini extract induced reactive oxygen species-mediated apoptosis in human oral squamous carcinoma cells. J Oral Pathol Med. 2019 Feb;48(2):115-121.Pubmed PMID: 30451321.

[60]. Mathew MG, Samuel SR, Soni AJ, Roopa KB. Evaluation of adhesion of Streptococcus mutans, plaque accumulation on zirconia and stainless steel crowns, and surrounding gingival inflammation in primary molars: randomized controlled trial. Clin Oral Investig. 2020 Sep;24(9):1-6.Pubmed PMID: 31955271

[61]. Samuel SR. Can 5-year-olds sensibly self-report the impact of developmental enamel defects on their quality of life? Int J Paediatr Dent. 2021 Mar;31(2):285-286.Pubmed PMID: 32416620.

[62]. R H, Ramani P, Ramanathan A, R JM, S G, Ramasubramanian A, et al. CYP2 C9 polymorphism among patients with oral squamous cell carcinoma and its role in altering the metabolism of benzo[a]pyrene. Oral Surg Oral Med Oral Pathol Oral Radiol. 2020 Sep;130(3):306-312.Pubmed PMID: 32773350 .

[63]. Chandrasekar R, Chandrasekhar S, Sundari KKS, Ravi P. Development and validation of a formula for objective assessment of cervical vertebral bone age. Prog Orthod. 2020 Oct 12;21(1):38.Pubmed PMID: 33043408.

[64]. Vijayashree Priyadharsini J, Smiline Girija AS, Paramasivam A. In silico analysis of virulence genes in an emerging dental pathogen A. baumannii and related species. Arch Oral Biol. 2018 Oct;94:93-98.Pubmed PMID: 30015217. 